\title{
Analisis Laba terhadap Kemampuan Membayar Zakat Bank Muamalat
}

\author{
Annisa Husna Harahap', Abdul Nasser Hasibuan², Ali Hardana ${ }^{3}$ \\ 1,2,Institut Agama Islam Negeri Padangsidimpuan
}

JL. H.T. Rizal Nurdin Km 4,5 Sihitang Kota Padangsidimpuan _ Sumatera Utara

Email: annisahusnahrp@gmail.com¹, abdulnasser@iain-padangsidimpuan.ac.id², alihardana@iain-padangsidimpuan.ac.id3

\begin{abstract}
Zakat is one of the social activities carried out by Bank Muamalat and which must be paid when it reaches the nisab. Calculation of zakat funds issued 2.5\% of profit before tax. Based on data obtained from Bank Muamalat, the percentage of Profit and Zakat fluctuated in 2013-202O, but the increase in the percentage that occurred in profit was not always followed by an increase in zakat. This study aims to determine whether profit has an effect on the ability to pay zakat in Bank Muamalat. This research is a quantitative research with data processing using SPSS version 23 computer program. The results of this study explain that profit has an effect on the ability to pay zakat in Bank Muamalat.
\end{abstract}

Keywords : Profit, Zakat, Muamalat Bank

\begin{abstract}
ABSTRAK
Zakat merupakan salah satu kegiatan sosial yang diemban Bank Muamalat dan yang wajib dibayar apabila sudah mencapai nisab. Perhitungan dana zakat yang dikeluarkan 2,5\% dari laba sebelum pajak. Berdasarkan data yang diperoleh dari Bank Muamalat persentase Laba dan Zakat mengalami fluktuasi pada tahun 2013-2020, namun kenaikan persentase yang terjadi pada laba tidak selalu diikuti dengan kenaikan zakat. Penelitian ini bertujuan untuk mengetahui apakah laba berpengaruh terhadap kemampuan membayar zakat Bank Muamalat. Penelitian ini adalah penelitian kuantitatif dengan proses pengolahan data menggunakan program komputer SPSS versi 23. Hasil penelitian ini menjelaskan bahwa laba berpengaruh terhadap kemampuan membayar zakat Bank Muamalat.
\end{abstract}

Kata Kunci: Laba, Zakat, Bank Muamalat 


\section{PENDAHULUAN}

Perkembangan bisnis bank di Indonesia ditandai dengan jumlah bank yang semakin banyak. Bagi suatu negara, bank dapat dikatakan sebagai darahnya perekonomian suatu negara. Dengan kata lain, kemajuan suatu bank di suatu negara dapat pula dijadikan sebagai ukuran negara yang bersangkutan. Semakin maju suatu negara, maka semakin besar peranan perbankan dalam mengendalikan negara tersebut. Artinya keberadaan dunia perbankan semakin dibutuhkan pemerintah dan masyarakatnya. Bank dijadikan sebagai tempat untuk melakukan berbagai transaksi yang berhubungan dengan keuangan seperti tempat pengamanan uang, melakukan investasi, pengiriman uang, melakukan pembayaran serta melakukan penagihan, oleh karena itu diperlukan berbagai penyesuaian kebijakan di bidang ekonomi termasuk sektor perbankan sehingga diharapkan dapat memperkuat perekonomian nasional (Pipi Sumanni Manullang, dkk : 2020, 105).

Perbankan Syariah sebagaimana halnya perbankan pada umumnya merupakan lembaga intermediasi keuangan (financial intermediary institution) yakni lembaga yang melakukan kegiatan menghimpun dana dari masyarakat dalam bentuk simpanan dan menyalurkannya kepada masyarakat lain yang membutuhkan dalam bentuk kredit atau pembiayaan. Sebagai lembaga keuangan bank merupakan institusi yang erat dengan pengaturan sehingga dikatakan bahwa perbankan merupakan the most heavy regulated industry in the world. Adanya merupakan suatu keniscayaan mengingat bank merupakan lembaga yang eksistensinya sangat membutuhkan adanya kepercayaan masyarakat (fiduciary relation) (ayu retno wahyuni 2020).

(iwan triyuwono : 2009, 32) telah mengajukan konsep bahwa, dalam bentuk yang operasional, metafora "amanah" bisa diturunkan menjadi metafora "zakat", atau realitas organisasi yang dimetaforakan dengan zakat (zakat metaphorised organisational reality). Ini artinya adalah bahwa organisasi bisnis orientasinya tidak lagi profit-oriented, atau "stockholders-oriented," tetapi zakat oriented dan environment dan stockholders-oriented.

Bank Syariah mempunyai fungsi sosial salah satunya melalui zakat. Secara terminologi zakat berarti membersihkan atau mensucikan. Dan zakat secara bahasa berasal dari kata “tajkiah” berarti an-nama' (tumbuh), at-taharah (bersuci), wa al-islah (kebaikan). Karena harta dibersihkan dengan adanya perintah ini, seseorang akan diampuni dan akan suci dengannya. Adapun secara etimologis (syara'), zakat diartikan sebagai sejumlah harta tertentu yang diwajibkan oleh Allah untuk diserahkan kepada golongan yang berhak (asnaf zakat), disamping mengeluarkan infak dan sedekah. Zakat memliki peran penting sebagai sumber pemasukan negara. Selain didasarkan kepada al-qur'an dan sunnah sehingga menjadi sebagai 
sarana untuk ibadah. Zakat juga berfungsi sebagai pemerataan pendapatan, pertumbuhan, dan kesejahteraan (Rahmad Hakim : 2020, 43).

Bagi bank syariah profitabilitas/laba dan kemampuan membayar zakat merupakan satu ukuran bersama yanga berjalan sekaligus. Zakat merupakan kewajiban bagi muslim, dan bagi bank syariah merupakan suatu bentuk pertanggungjawaban sosial bagi masyarakat (Aida Maudi, dkk : 2020, 76), dalam penelitian ini konteks laba yang digunakan adalah laba bersih. Hal ini disebabkan karena laba bersih dipandang mampu mencerminkan secara langsung kinerja operasional sebuah perusahaan. Dengan laba yang diperoleh perusahaan dapat mempertahankan kelangsungan hidup perusahaan dan mengembangkan usaha menuju yang lebih baik. (Soemarso : 2014, 43)Berikut ini adalah tabel data dari laba bersih dan zakat perusahaan.

Tabel 1

Data Laba Bersih dan Data Zakat Dalam Jutaan Rupiah

\begin{tabular}{|c|c|c|}
\hline Tahun & Laba Bersih (X) & Zakat (Y) \\
\hline \multirow[t]{4}{*}{2013} & 187.058 .000 & 2.063 .000 \\
\hline & 385.712 .000 & 13.986 .000 \\
\hline & 596.185 .000 & 16.231 .000 \\
\hline & 708.677 .000 & 18.509 .000 \\
\hline \multirow[t]{4}{*}{2014} & 204.557 .000 & 2.180 .000 \\
\hline & 304.281 .000 & 4.960 .000 \\
\hline & 68.761.000 & 19.509 .000 \\
\hline & 147.852 .000 & 22.723 .000 \\
\hline \multirow[t]{4}{*}{2015} & 96.659 .000 & 2.714 .000 \\
\hline & 155.084 .000 & 5.619 .000 \\
\hline & 177.932 .000 & 8.513 .000 \\
\hline & 40.319 .000 & 12.533 .000 \\
\hline \multirow[t]{4}{*}{2016} & 40.319 .000 & 2.935 .000 \\
\hline & 11.762 .000 & 7.693 .000 \\
\hline & 48.893 .000 & 10.422 .000 \\
\hline & 85.766 .000 & 13.002 .000 \\
\hline \multirow[t]{4}{*}{2017} & 22.705 .000 & 2.544 .000 \\
\hline & 61.828 .000 & 7.132 .000 \\
\hline & 60.463 .000 & 9.69 .000 \\
\hline & 43.492 .000 & 10.869 .000 \\
\hline 2018 & 171.377 .000 & 2.500 .000 \\
\hline
\end{tabular}

JISFIM: Journal of Islamic Social Finance Management, Volume 2, No 2 Tahun 2021 http://jurnal.iain-padangsidimpuan.ac.id/index.php/JISFIM 


\begin{tabular}{|c|c|c|}
\hline & 155.834 .000 & 5.043 .000 \\
\hline & 171.377 .000 & 8.217 .000 \\
\hline 2019 & 68.870 .000 & 10.586 .000 \\
\hline & 8.889 .000 & 2.295 .000 \\
\hline & 19.063 .000 & 5.058 .000 \\
\hline 2020 & 34.279 .000 & 8.616 .000 \\
\hline & 19.508 .000 & 10.869 .000 \\
\hline & 27.371 .000 & 2.182 .000 \\
\hline & 35.978 .000 & 6.328 .000 \\
\hline & 16.392 .000 & 10.293 .000 \\
\hline
\end{tabular}

Sumber: www.bankmuamalat.co.id

Dari tabel 1 diatas kita ketahui bahwa zakat dan laba mengalami fluktuasi. Berdasarkan tabel 1 di atas laba bersih Bank Muamalat pada tahun 2015 quarter pertama sebesar Rp 96.659.00o dan quarter kedua sebesar Rp 155.084.000 atau mengalami kenaikan sebesar Rp 58.425.000 Pada tahun 2016 quarter pertama sebesar Rp 40.319.0oo dan quarter kedua sebesar Rp 11.762.000 atau menurun sebesar Rp 28.557.00o Sedangkan pada tahun 2017 quarter pertama sebesar Rp 22.705.000 dan quarter kedua sebesar Rp 61.828.000 atau mengalami kenaikan sebesar Rp 39.123.00o Pada tahun 2018 quarter ketiga sebesar Rp 171.377.00o dan quarter keempat sebesar Rp 68.870.000 atau mengalami penurunan sebesar Rp 102.507.000 Mengacu pada laba bersih terendah pada tahun 2019 pada quarter pertama sebesar Rp 8.889.00o dan laba bersih tertinggi pada tahun 2013 quarter keempat sebesar Rp 708.677.000.

Fluktuasi yang terjadi pada laba bersih tidak sesuai dengan zakat yang dikeluarkan Bank Muamalat yang mengalami peningkatan setiap quarternya. Dimana pada tahun 2016 quarter kedua sebesar Rp 7.693.00o dan pada quarter ketiga sebesar Rp 10.422.000 yaitu mengalami kenaikan sebesar Rp 2.729.00o dan pada tahun 2017 quarter pertama sebesar Rp 2.544.00o dan quarter kedua sebesar Rp 7.132.000 atau mengalami kenaikan sebesar Rp 4.588.0oo Pembayaran zakat terendah Bank Muamalat pada tahun 2013 quarter pertama sebesar Rp 2.063.000 dan zakat tertinggi pada Bank Muamalat pada tahun 2014 quarter keempat sebesar Rp 22.723.000.

Dari gambaran laporan keuangan laba bersih dan zakat perusahaan diatas mengalami fluktuasi, dapat diketahui bahwa kinerja perusahaan yaitu semakin tinggi zakat yang dikeluarkan oleh perusahaan berarti semakin besar laba yang didapat perusahaan. Berdasarkan teori tersebut seharusnya pada waktu laba meningkat maka zakat Bank http://jurnal.iain-padangsidimpuan.ac.id/index.php/JISFIM 
Muamalat akan meningkat karena pada posisi tersebut bank menunjukkan efektifitas dalam mecari laba (Muhammad : 2011, 44).

Berdasarkan latar belakang masalah di atas peneliti tertarik untuk melakukan penelitian untuk menuangkan masalah ini ke dalam sebuah skripsi guna memperoleh gelar kesarjanaan dengan judul "Analisis Pengaruh Laba Terhadap Kemampuan Membayar Zakat Bank Muamalat”.

\section{METODE PENELITIAN}

Jenis penelitian ini adalah penelitian kuantitatif. Data kuantitatif yaitu data yang berupa angka. Sesuai dengan bentuknya data kuantitatif dapat dioalah atau dianalisis dengan menggunakan teknik perhitungan statistik. Metode ini menggunakan pendekatan deskriptif, karena penelitian ini dilakukan untuk mengumpulkan data yang akan diuji dan atau menjawab pertanyaan mengenai status terakhir suatu objek yang diteliti. Penelitian ini dilakukan berdasarkan runtun waktu (time series), time series adalah data yang dikumpulkan dari waktu kewaktu pada satu obbjek dengan tujuan untuk menggambarkan peerkembangan dari objek tersebut (Syofian Siregar : 2013, 16).

Populasi dalam penelitian ini adalah laporan keuangan pada Bank Muamalat dari tahun 2013 sampai tahun 2020 dengan menggunakan data quarter sebanyak 32 data laporan keuangan. sempel yang digunakan dalam penelitian ini merupakan sampel jenuh dimana teknik penentuan sampel semua anggota populasi digunakan sebagai sampel. Sumber data penelitian ini adalah data sekunder. Variabel yang akan dianalisis pada penelitian ini adalah variabel laba sebagai variabel independen dan zakat sebagai variabel dependen. Teknik analisis dalam peneilitain ini adalah analisis uji normalitas data, uji deskriptif, uji analisis regresi linier sederhana, uji hipotesis, koefisien determinasi.

\section{HASIL DAN PEMBAHASAN}

\section{Laba}

Laba adalah hasil penandingan antara pendapatan dengan beban. Manajemen harus bisa memprediksi besarnya pendapatan yang harus diperoleh dan beban yang akan dikeluarkan perusahaan dimasa yang akan datang agar perusahaan tidak menderita kerugian. laba bermanfaat bagi perusahaan untuk kelangsungan hidupnya serta untuk mengukur keberhasilan perusahaan (Hery : 2017, 85).

Laba merupakan kenaikan modal aktiva bersih yang berasal dari transaksi sampingan atau transaksi yang jarang terjadi dari suatu badan usaha, dan dari semua transaksi atau kejadian lain yang mempengaruhi badan usaha selama suatu periode kecuali yang timbul dari pendapatan (revune) atau investasi oleh pemiliknya (Yahya Pudin Shatu : 2016,68). Laba

JISFIM: Journal of Islamic Social Finance Management, Volume 2, No 2 Tahun 2021 http://jurnal.iain-padangsidimpuan.ac.id/index.php/JISFIM 
merupakan angka yang penting dalam laporan keuangan karena berbagai alasan antara lain; Laba merupakan dasar perhitungan pajak; Pedoman dalam menentukan kebijakan investasi dan pengambilan keputusan, dasar dalam peramalan laba maupun kejadian ekonomi perusahaan lainnya dimasa yang akan datang; dasar dalam peramalan laba maupun kejadian ekonomi perusahaan lainnya dimasa yang akan datang; dasar dalam perhitungan dan penilaian efisiensi dalam menjalankan perusahaan; Serta sebagai dasar dalam penilaian prestasi atau kinerja perusahaan (Muhammad Rizal Nur Irawan : 2016, 15).

Secara bahasa laba berarti pertumbuhan dalam dagang. Salah satu tujuan usaha (dagang) adalah untuk mencapai laba. Dimana laba merupakan gambaran dari pertumbuhan harta. Laba itu muncul karena terjadinya proses perputaran modal dan pengoperasiannya dalam kegiatan-kegiatan dagang dan moneter. Secara umum kriteria penentuan batas laba dalam islam adalah sebagai berikut; a) Kelayakan dalam penetapan laba, Islam menganjurkan agar para pedagang tidak berlebihan dalam mengambil laba. Pernyataan ini menjelaskan bahwa batasan laba ideal (pantas dan wajar) dapat melakukan dengan merendahkan harga. Keadaan ini akan menimbulkan perputaran barang secara cepat dan meningkatnya peranan uang yang pada akhirnya akan berdampak pada peningkatnya peranan uang yang pada akhirnya akan berdampak pada peningkatan laba, b) Keseimbangan antara tingkat kesulitan dan laba, Islam menghendaki keseimbangan antara standar laba dan tingkat kesulitan perputaran serta perjalanan modal. Semakin tingkat kesulitan dan resiko, maka semakin besar pula laba yang diinginkan pedagang; c) Masa perputaran modal, peranan modal berpengaruh terhadap standarisasi laba yang diinginkan oleh pedagang, yaitu dengan semakin lama masa perputaran dan bertambahnya tingkat resiko, maka semakin tinggi pula standar laba yang diinginkan pedagang atau pengusaha; d) Cara menutupi harga penjualan, ada 2 macam cara pembayaran harga, yaitu pembayaran tunai dan pembayaran kredit. Jual beli yang pembayarannya sampai batas waktu tertentu hukumnya boleh jika jual beli itu terlengkapi syarat-syarat yang telah disepakati (akad) antara penjual dan pembeli; e) Unsurunsur pendukung, unsur-unsur seperti keadaan yang berubah dari waktu kewaktu dapat memberikan dampak terhadap usaha yang mempengaruhi laba. Selagi unsur-unsur tersebut tidak bertentangan dengan kaidah hukum-hukum islam maka diperbolehkan (Aida Maudi, dkk : 2020, 34).

Laba adalah keuntungan yang mencerminkan pencapaian dari suatu perusahaan dalam hubungannya terhadap usaha selama satu periode tertentu. Menurut laba yang besar bukanlah merupakan ukuran bahwa bank telah bekerja secara efisien. Efisien dapat diketahui dengan membandingkan laba yang diperoleh dengan kekayaan atau dengan menghitung profitabilitasnya. Rasio profitabilitas adalah rasio untuk mengukur efektifitas bank dalam memperoleh laba. Adapun analisis rasio profitabilitas menurut Lukman Dendawijaya adalah 
alat untuk mengukur tingkat efisiensi usaha dan profitabilitas yang dicapai oleh bank yang bersangkutan.

\section{Zakat}

Zakat adalah sebagian dari harta yang wajib dikeluarkan oleh wajib zakat (muzakki) untuk diserahkan kepada penerima zakat (mustahiq). Pembayaran zakat dilakukan apabila nisab dan haulnya terpenuhi dari harta yang memenuhi kriteria wajib zakat (Ahmad Sudirman Abbas : 2017, 10). Zakat adalah sebagian harta yang wajib dikeluarkan oleh wajib zakat untuk diserahkan kepada penerima zakat. Pembayaran zakat dilakukan apabila nisab dan haulnya terpenuhi dari harta yang memenuhi kriteria wajib zakat (PSAK 101 paragraf 71). Unsur dasar laporan sumber dan penggunaan dana zakat meliputi sumber dana, penggunaan dana, penggunaa dana selama suatu dana zakat waktu, serta saldo dana zakat yang menunjukkan dana zakat yang belum disalurkan pada tanggal tertentu (paragraf 72). Dalam hal ini, dana zakat tidak diperkenankan untuk menutup cadangan korupsi aset produktif. Sumber dana zakat di Bank Syariah terdiri dari; Zakat dari dalam entitas Bank Syariah; Dana zakat dari pihak luar entitas Bank Syariah (termasuk zakat dari nasabah.

Zakat merupakan salah satu rukun Islam. Kewajiban zakat memiliki hubungan dan keterkaitan yang erat dengan rukun Islam lainnya. Jika shalat merupakan kewajiban badaniyah maka zakat merupakan kewajiban yang dikenakan pada harta kekayaan setiap muslim. Al-Qur'an menyatakan bahwa zakat itu diambil dari setiap harta yang kita miliki, seperti dikemukakan dalam surah at-Taubah ayat 103 dan juga diambil dari setiap hasil usaha yang baik dan halal, seperti juga digambarkan dalam surah al-Baqarah ayat 267. Begitu juga dengan landasan hukum kewajiban zakat pada perusahaan adalah seperti yang termaktub dalam surah at-Taubah ayat 103 dan al -Baqarah ayat 267. Nisab zakat perusahaan sama dengan nisab zakat perdagangan dan sama dengan nisab zakat emas dan perak. Menurut pendapat yang mu'tamar (akurat), 20 misqal itu sama dengan 85 gram emas ( Pipi Sumanni Manullang, dkk : 2020, 107).

Zakat termasuk sedekah, bedanya kalau zakat hukumnya wajib sementara sedekah hukumnya sunnah. Nabi menjelaskan bahwa sedekah akan membuahkan tiga hal, yaitu bisa memadamkan kemurkaan Allah, bisa menyebabkan rizki menjadi barokah dan bisa menarik rizki yang banyak (Hamni Fadilah Nasution, dkk : 2020, 234). Kewajiban zakat perusahaan di Indonesia diatur dalam Undang-undang No. 38 Tahun 1999 tentang Pengelolaan Zakat, dimana bank syariah wajib mengeluarkan zakat yang dijelaskan pada Bab IV pasal 11 ayat (2) bagian (b) dikemukakan bahwa diantara wajib zakat yang wajib dikeluarkan zakatnya adalah perdagangan dan perusahaan. Kemampuan zakat perusahaan dapat dilihat dari hasil laporan keuangan yang bukan hanya sekedar dinyatakan dalam bentuk angka-angka persentase, akan

JISFIM: Journal of Islamic Social Finance Management, Volume 2, No 2 Tahun 2021 http://jurnal.iain-padangsidimpuan.ac.id/index.php/JISFIM 
tetapi melalui zakat dapat diketahui bagaimana kinerja suatu perusahaan, yaitu semakin tinggi zakat yang dikeluarkan oleh perusahaan berarti semakin besar laba yang didapat perusahaan. Adapun laba yang dimaksud adalah laba sebelum zakat. Penelitian ini berkaitan dengan laba bersih, berarti semakin tinggi zakat yang dikeluarkan oleh perusahaan, maka semakin rendah laba bersih yang didapat perusahaan (Pipi Sumanni Manullang, dkk: 2020, 107).

\section{Perusahaan sebagai Subjek Zakat Menurut Tinjauan Perundangan}

Sebagaimana disebutkan sebelumnya bahwa kewajiban zakat bagi perusahaan masih memiliki dua pandangan yang berbeda di kalangan ulama. Perbedaan pendapat ini disebabkan karena memang lembaga badan hukum seperti perusahaan itu memang belum ada teks yang mewajibkannya sehingga ulama fiqh generasi pertama tidak mewajibkan zakat. Tetapi umumnya ulama kontemporer yang mendalami masalah zakat, mengkategorikan perusahaan sebagai wajib zakat. Pandangan ulama kontemporer ini rupanya banyak diikuti oleh legislator di Indonesia. Hal ini terbukti dari banyaknya perundangan yang menyebutkan bahwa subjek zakat bukan hanya perorangan muslim saja, namun lembaga maupun badan hukum juga diakui sebagai subjek zakat. Salah satunya adalah Undang-Undang Republik Indonesia Nomor 38 tahun 1999 tentang pengelolaan zakat (Parman Komaruddin dan muhammad Rifki Hidayat : 2018, 38).

Sebagaimana yang disebutkan dalam angka tiga pasal tersebut, yang dimaksud dengan Muzakki adalah seorang muslim dan badan yang dimiliki oleh orang muslim. Aturan ini kemudian dilengkapi oleh undang-undang nomor 23 tahun 2011 tentang Pengelolaan zakat, dimana istilah badan tersebut ditambah menjadi badan usaha. Hal ini dapat dipahami mengingat tidak semua badan bergerak di bidang usaha. Sebagian hanya bergerak di bidang sosial sehingga tidak tepat untuk diwajibkan zakatnya, bahkan sebaliknya ia dapat dianggap sebagai mustahiq zakat seperti panti asuhan yang merawat anak-anak yatim-piatu. Sedangkan badan usaha sejenis perusahaan yang bergerak dalam bidang usaha untuk memperoleh keuntungan dapat diwajibkan zakatnya.

\section{Laporan Keuangan}

Menurut (Kasmir : 2012, 35) laporan keuangan adalah laporan yang menunjukkan kondisi keuangan perusahaan pada saat ini atau dalam satu periode tertentu.tujuan laporan keuangan pada sektor perbankan syariah adalah untuk menyediakan informasi yang menyangkut posisi keuangan, kinerja serta perubahan posisi keuangan aktivitas operasi perbankan yang bermanfaat dalam pengambilan keputusan.

Tujuan khusus laporan keuangan adalah menyajikan secara wajar dan sesuai dengan prinsip akuntansi yang berlaku umum mengenai posisi keuangan, hasil usaha, dan perubahan lain dalam posisi keuangan. Sedangkan dalam statistik akuntansi keuangan (SAK) dijelaskan tentang tujuan laporan keuangan yang isinya "tujuan laporan keuangan adalah menyediakan JISFIM: Journal of Islamic Social Finance Management, Volume 2, No 2 Tahun 2021 http://jurnal.iain-padangsidimpuan.ac.id/index.php/JISFIM 
informasi yang menyangkut posisi keuangan, kinerja, serta perubahan posisi keuangan suatu perusahaan yang bermanfaat bagi sejumlah besar pemakai dalam pengambilan keputusan ekonomi."(Hery : 2017, 89) tujuan utama dari laporan keuangan adalah memberikan informasi yang berguna untuk pengambilan keputusan ekonomis. Para pemakai laporan akan menggunakannya untuk meramalkan, membandingkan, dan menilai dampak keuangan yang timbul dari keputusan ekonomis yang diambilnya. Informasi mengenai dampak keuangan yang timbul tadi sangat berguna bagi pemakai untuk meramalkan, membandingkan dan menilai arus kas. Seandainya nilai uang tidak stabil, maka hal ini akan dijelaskan dalam laporan keuangan.

\section{Uji normalitas}

Uji normalitas yang digunakan adalah metode uji one sample kolmogrov Smirnov. Uji one sample kolmogrov smirnov digunakan untuk mengetahui distiribusi data, apakah mengikuti distribusi normal, poisson, uniform, atau exponential. Dalam hal ini untuk mengetahui apakah distribusi residual terdistribusi normal atau tidak apabila nilai signifikansi lebih dari o,05. Tabel di bawah ini menunjukkan hasil uji normalitas variabel laba bersih dan zakat dengan metode kolmogrov smirnov.

\section{Tabel 2}

\begin{tabular}{llrr}
\hline \multicolumn{2}{c}{ Keterangan } & Laba Bersih & \multicolumn{1}{c}{ Zakat } \\
\hline $\mathrm{N}$ Normal Parameters & a,b & 32 & 32 \\
& Mean & 131041,28 & 8173,84 \\
& Std. & 163958,715 & 5652,166 \\
Most Extreme & Deviation & 0,228 & 0,116 \\
Differences & Absolute & 0,210 & 0,116 \\
& Positive & $-0,228$ & $-0,109$ \\
Test Statistic & Negative & 0,228 & 0,116 \\
Asymp. Sig. (2-tailed) & & $0,192^{\mathrm{c}}$ &, $200^{\mathrm{c}, \mathrm{d}}$ \\
\hline
\end{tabular}

Berdasarkan tabel di atas terlihat bahwa nilai absolut dari laba bersih sebesar 0,192 dan zakat sebesar 0,200 artinya > 0,05. Jadi, dapat disimpulkan bahwa data variabel laba dan zakat terdistribusi normal dengan menggunakan uji kolmogorov-smirnov.

\section{Uji deskriptif}

Tabel 3

Uji deskriptif

\begin{tabular}{lrrrrr}
\hline Keterangan & N & Minimum & Maximum & \multicolumn{1}{c}{ Mean } & \multicolumn{1}{c}{ Std. Deviation } \\
\hline Laba Bersih & 32 & 8889 & 708677 & 131041,28 & 163958,715 \\
Zakat & 32 & 969 & 22723 & 8173,84 & 5652,166 \\
Valid N & & & & & \\
(listwise) & 32 & & & & \\
\hline
\end{tabular}

JISFIM: Journal of Islamic Social Finance Management, Volume 2, No 2 Tahun 2021 http://jurnal.iain-padangsidimpuan.ac.id/index.php/JISFIM 
Sumber:hasil spss 23.

Berdasarkan tabel di atas diketahui bahwa rata-rata laba bersih adalah 131041,28 dan rata-rata zakat 8173,84 . Untuk nilai minimum laba bersih sebesar 8889 , dan nilai minimum zakat sebesar 969. Untuk nilai maksimum laba bersih sebesar 708677, dan maksimum zakat sebesar 22723 Standar deviasi laba bersih sebesar 163958,715 dan standar deviasi zakat sebesar 5652,166.

\section{Uji regresi linier sederhana}

Analisis regresi digunakan untuk mengetahui besarnya pengaruh variabel independen dan variabel dependen. Pada bagian ini, model regresi yang diterapkan untuk menguji pengaruh variabel independen yaitu laba terhadap zakat perusahaan adalah model regresi linear sederhana dengan menggunakan metode enter. Metode enter adalah metode yang memasukkan semua variabel independen dalam persamaan regresi. Data-data diolah menggunakan software SPSS 23 for windows. Berdasarkan perhitungan melalui software SPSS tersebut diperoleh hasil regresi sebagai berikut:

Tabel 4

Uji regresi linier sederhana

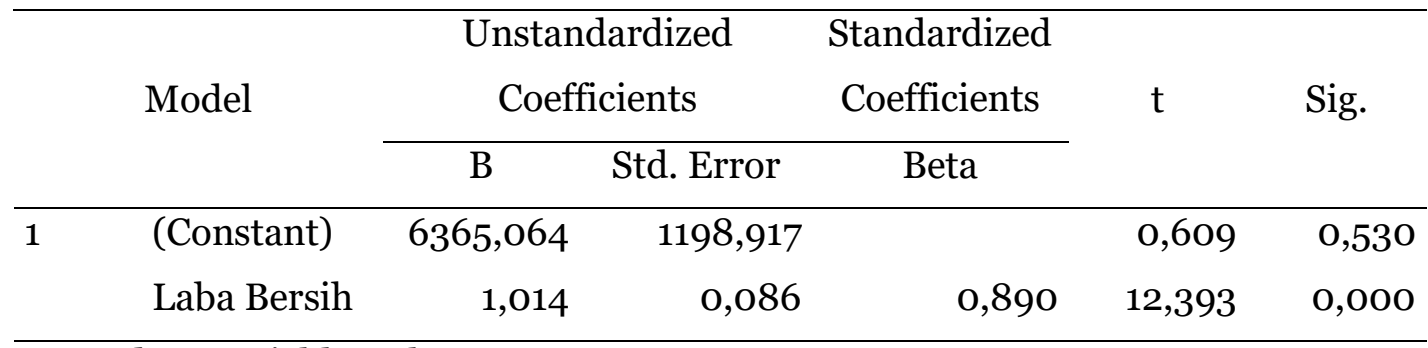

Dependent Variable: zakat

Dari hasil analisis dengan software SPSS 23 tersebut, maka dapat diketahui persamaan regresi yang terbentuk adalah

$\mathrm{Y}=\mathrm{a}+\mathrm{bX}$

$\mathrm{Y}=6365,064+1,014 \mathrm{X}$

Keterangan:

$\mathrm{Y}=$ Zakat

$\mathrm{a}=$ Konstanta

$\mathrm{b}=$ Koefisien Regresi

$\mathrm{X}=$ Laba

Persamaan regresi tersebut dapat dijelaskan sebagai berikut: Nilai konstanta sebesar 6365,064 artinya jika laba bersih tetap maka tingkat zakat sebesar 6365,064 satuan.

\section{Uji hipotesis}

Uji t digunakan untuk mengetahui pengaruh variabel independen (laba) terhadap dependen (zakat). Uji t bertujuan untuk mengetahui pengaruh variabel laba dan zakat. JISFIM: Journal of Islamic Social Finance Management, Volume 2, No 2 Tahun 2021 http://jurnal.iain-padangsidimpuan.ac.id/index.php/JISFIM 
Dengan ketentuan $t_{\text {hitung }}>t_{\text {tabel }}$ maka $H_{o}$ ditolak dan $H_{a}$ diterima, jika $t_{\text {hitung }}<t_{\text {tabel }}$ maka $H_{o}$ diterima $\mathrm{H}_{\mathrm{a}}$ ditolak. Hasil analisis regresi pada uji t dapat dilihat pada tabel di bawah ini :

Tabel 5

Uji Hipotesis

\begin{tabular}{|c|c|c|c|c|c|c|}
\hline & \multirow[t]{2}{*}{ Model } & \multicolumn{2}{|c|}{$\begin{array}{c}\text { Unstandardized } \\
\text { Coefficients }\end{array}$} & \multirow{2}{*}{$\begin{array}{c}\text { Standardized } \\
\text { Coefficients } \\
\text { Beta }\end{array}$} & \multirow[t]{2}{*}{$\mathrm{t}$} & \multirow[t]{2}{*}{ Sig. } \\
\hline & & B & Std. Error & & & \\
\hline \multirow[t]{2}{*}{1} & (Constant) & 6365,064 & 1198,917 & & 5,309 & 0,530 \\
\hline & Laba Bersih & 1,014 & 0,086 & 0,890 & 12,393 & 0,000 \\
\hline
\end{tabular}

Dependent Variable: zakat

Dari hasil uji hipotesis (uji $\mathrm{t}$ ) diatas dapat dilihat pada variabel laba memiliki $t_{\text {hitung }}$ sebesar 12,393 dan $t_{\text {tabel }}$ sebesar 2,04227 sehingga $t_{\text {hitung }}>t_{\text {tabel }}(12,393>2,04227)$ maka $H_{a}$ diterima. Jadi dapat disimpulkan bahwa secara parsial laba berpengaruh yang signifikan terhadap zakat.

\section{Uji koefisien determinasi}

Kekuatan pengaruh variabel bebas terhadap variasi varibel terikat dapat diketahui dari besarnya koefisien determinasi $\left(\mathrm{R}^{2}\right)$. Hasil perhitungan koefisien determinasi dapat dilihat pada tabel berikut:

Tabel 6

Uji Koefisien Determinasi

\begin{tabular}{lrrrr}
\hline Model & R & R Square & $\begin{array}{c}\text { Adjusted R } \\
\text { Square }\end{array}$ & $\begin{array}{r}\text { Std. Error of } \\
\text { the Estimate }\end{array}$ \\
\hline 1 & $0,810^{\mathrm{a}}$ & 0,760 & 0,732 & 27264,915 \\
\hline
\end{tabular}

Tabel diatas menunjukkan nilai R square sebesar 0,760. Hal ini berarti 76,0\% zakat perusahaan dipengaruhi oleh laba bersih, sedangkan sisanya 24\% dipengaruhi oleh variabelvariabel lain.

\section{Pembahasan hasil penelitian}

Berdasarkan hasil analisis dan pengujian hipotesis yang telah dilakukan, maka diperoleh hasil yang menunjukkan bahwa hipotesis alternatif yang menyatakan ada pengaruh antara laba bersih terhadap zakat. Dari hasil uji hipotesis dapat dilihat pada variabel laba bersih memiliki $t_{\text {hitung }}$ sebesar 12,393 dan $t_{\text {tabel }}$ sebesar 2,04227 sehingga $t_{\text {hitung }}>t_{\text {tabel }}(12,393$ >2,04227) maka $\mathrm{H}_{\mathrm{a}}$ diterima. Jadi dapat disimpulkan bahwa secara parsial laba bersih berpengaruh yang signifikan terhadap zakat.

Hasil ini diperkuat dengan hasil penelitian terdahulu oleh rahayu nigsih Dengan hasil perhitungan didapat $F_{\text {hitung }}$ sebesar 47,154 dengan $F_{\text {tabel }}$ sebesar5,99. Hal ini berarti $F_{\text {hitung }}>$

JISFIM: Journal of Islamic Social Finance Management, Volume 2, No 2 Tahun 2021 http://jurnal.iain-padangsidimpuan.ac.id/index.php/JISFIM 
$\mathrm{F}_{\text {tabel, }}$ yang menunjukkan bahwa laba usaha berpengaruh terhadap zakat PT Bank Syariah Mandiri. Untuk uji t, diperoleh $t_{\text {hitung }}$ sebesar 6,867 dengan $t_{\text {tabel }}$ sebesar 2,447. Hal ini berarti laba usaha mempunyai pengaruh signifikan terhadap kemampuan membayar zakat.

Hasil penelitian ini didukung dengan penelitian terdahulu yang dilakukan Sri Zaitun, Ahmad Nurul Muammar, dan Khoirul Ikhwan. dimana Sri Zaitun memperoleh hasil variabel Return On Assets (ROA), Return On Equity (ROE), Loan Deposit Ratio (LDR), current rasio (CR), Debt to Assets Ration (DAR) dan Equity Multiflier (EM) secara simultan berpengaruh secara statistik signifikan terhadap zakat. Ahmad Nurul Muammar memperoleh hasil rasio profitabilitas yang di ukur dengan ROA dan ROE secara bersama-sama (simultan) berpengaruh signifikan terhadap kemampuan zakat. Begitu pula hasil yang diperoleh Khoirul Ikhwan, hasil yang diperoleh menunjukkan bahwa variabel bebas (kinerja keuangan: profitabilitas, likuiditas, solvabilitas) secara bersamaan maupun sendiri mempunyai pengaruh yang kuat terhadap dana zakat Variabel nilai kinerja keuangan mempunyai pengaruh yang dominan terhadap dana zakat. Ini sesuai dengan teori bahwa untuk pencapaian kinerja keuangan yang baik akan membuat kinerja zakat baik juga.

Nilai R square sebesar 0,760. Hal ini berarti 76,0\% zakat perusahaan dipengaruhi oleh laba bersih, sedangkan sisanya 24\% dipengaruhi oleh variabel-variabel lain.

Hasil ini diperkuat dengan hasil penelitian terdahulu oleh Rahayu Ningsih yang menunjukkan nilai R square sebesar o,887. 88,7\% zakat perusahaan dipengaruhi oleh laba, sedangkan sisanya 11,3\% dipengaruhi oleh variabel-variabel lain. Dari hasil analisis data dapat terlihat bahwa laba usaha sangat erat kaitannya dengan zakat perusahaan. Laba usaha dan zakat perusahaan mempunyai hubungan berbanding lurus artinya apabila laba usaha meningkat maka zakat perusahaan pun meningkat, apabila laba usaha menurun maka zakat perusahaan pun menurun. Hal ini sesuai dengan teori bahwa zakat diperhitungkan berdasarkan faktor utama yaitu laba.

\section{KESIMPULAN}

dapat disimpulkan bahwa dari hasil uji hipotesis (uji t) dapat dilihat pada variabel laba bersih memiliki $t_{\text {hitung }}$ sebesar 12,393 dan $t_{\text {tabel }}$ sebesar 2,04227 sehingga $t_{\text {hitung }}>t_{\text {tabel }}(12,393$ $>2,04227$ ) maka $\mathrm{H}_{\mathrm{a}}$ diterima. Jadi dapat disimpulkan bahwa secara parsial laba berpengaruh yang signifikan terhadap zakat.

\section{DAFTAR PUSTAKA}

Ahmad Sudirman Abbas. 2017. Zakat: Ketentuan Dan Pengelolaannya. Bogor.

Aida Maudi dkk. 2020. "Determinasi Profitabillitas Sengan Ukuran Perusahaan Sebagai Variabel Moderasi Bank Umum Syariah” 1: 34. 
Hamni Fadlilah Nasution. 2020. "Determinan Tingkat Partisipasi Zakat Di Masa Pandemi Covid-19” 1.

Hery. 2017. Kajian Riset Akuntansi. Jakarta.

Iwan triyuwono. 2009. Perspektif, Metodologi, Dan Teori Akuntansi Syariah. Jakarta.

Kasmir. 2012. Analisis Lporan Keuangan. Jakarta: Raja Wali Pers.

Muhammad. 2011. Pengantar Akuntansi Syariah. Jakarta.

Muhammad Rizal Nur Irawan. 2016. "Pengaruh Modal Uaaha Dan Penjualan Terhadap Laba Usaha Pada Perusahaan Penggiling Padi UD. Sari Tani Tenggerejo Kedungpring Lamongan" 1.

Parman Komaruddin dan muhammad Rifki Hidayat. 2018. "Perusahaan Sebagai Subjek Dalam Perspektif Fikih Dan Peraturan Perunfangan" 4.

Pipi Sumanni Manullang, Nofinawati, Jumi Atika. 2020. "Pengaruh Zakat Terhadap Rasio Net Profit Margin (NPM) Pada PT. Bank Syariah Mandiri Tbk.” 1.

Rahmad Hakim. 2020. Manajemen Zakat Histori, Konsepsi Dan Implementasi. Jakarta.

Soemarso. 2014. Akuntansi Suatu Pengamtar Buku 1. Edisi Kelima. Jakarta.

Syofian Siregar. 2013. , Metode Penelitian Kuantitatif. Jakarta.

wahyuni, dkk ayu retno. 2020. Analisis Implementasi Good Corporate Govermance (GCG) Pada Bank Sulselbar Syariah. Vol. 4.

Yahya Pudin Shatu. 2016. Kuasai Detail Akuntansi Laba Dan Rugi. Jakarta. 